\title{
Integration and architectural issues of a photovoltaic/thermal linear solar concentrator
}

\author{
Alessandro Cappelletti $^{\mathrm{a}}$, Lucia Ceccherini Nelli ${ }^{\mathrm{b}, *}$, Alberto Reatti $^{\mathrm{c}}$ \\ ${ }^{\text {a }}$ Department of Industrial Engineering DIEF, University of Florence, Via Di Santa Marta 3, 50139 Florence, Italy \\ ${ }^{\mathrm{b}}$ Department of Architecture DIDA - Centro ABITA, University of Florence, via San Niccolò 93, Firenze, Italy \\ ${ }^{\mathrm{c}}$ Department of Information Engineering DINFO, University of Florence, Via Di Santa Marta 3, 50139 Florence, Italy
}

\section{A R T I C L E I N F O}

\section{Keywords:}

Integration of photovoltaic/thermal (PVT)

system

Solar concentrator

Solar panels

PV panels

Thermal concentrator

Building envelope integration

\begin{abstract}
A B S T R A C T
Modern photovoltaics and thermal technologies are widely available for the building sector at competitive prices. However, innovative approaches must be explored and implemented to find new architectural solutions at the building scale.

This paper presents an electro-thermal solar concentrator and proposals for its building integration. The proposed device has a small size and is based on a 20x semi-parabolic mirror concentrating the sunlight on a linear focus where a string of mono-crystalline PV cells is placed. A thermal receiver is placed on the back-side of the cells, a fluid circulating in the thermal receiver provides the heat recovery. The linear focus allows a monoaxial sun tracking. The proposed device has been numerically analyzed with the support of experimental data. The small size and the linear focus make feasible the integration of arrays of the proposed innovative device in roofs or façades of both new and existing buildings where they contribute to the auto-generation of a portion of the overall required energy. Several examples of the possibilities of array building integration of the described small-size solar concentrator are proposed. The device can be horizontally and/or vertically mounted to better match the architectural needs. The potential yearly power generation of a single unit three meters long, is evaluated to be as high as $120 \mathrm{kWh}_{\text {elettric }} /$ year and $500 \mathrm{kWh}_{\text {thermal }} /$ year. Horizontal mounting results in a power production about $30 \%$ higher than the vertical mounting.

The significance of this paper is that small size, single axis solar tracking, suitable for building integration is presented, studies of its possible integration in the building are given, the power generation capabilities of the proposed solutions are analyzed in detail. These capabilities have been derived using data achieved by experimental tests performed on a prototype constituted by four semi-parabolic mirrors. The novel contribution is that a new research direction toward further improvement of the performance, system design and installation of a prefabricated modular façade component, is presented. Moreover, the proposed PVT low concentrated solar device is integrable into buildings, easy to install and manage. Finally, the modern and attractive architectural designs are proposed.
\end{abstract}

\section{Introduction}

Building integration of active solar energy technologies represents a great potential for both architectural and cost benefits to achieve highquality standards for NZEB (Deng et al., 2014; Marique and Reiter, 2014) and represent a possible answer to recent European policies and IEA recommendations, (IEA SHC Task 41) which ask for more efficient buildings.

D'agostino and Parker (2018) show that an over 50\% reduction of natural gas and electricity consumption in the building is possible.

Solar energy is a significant source of energy for buildings and many projects investigated how this resource is exploitable; CPVT devices are an interesting example.

One advantage of PVT is that PV cells are cooled (Siecker et al., 2017), and this increases their efficiency. Moreover, the heat recovered from the cells is usefully utilized for hot water generation.

Good (2016) emphasizes how a PVT system can result in an average 4-6 year energy payback time (EPBT) while the expected device life is 20 years. Sharaf and Orhan (2015a, 2015b) presented a review of several CPVT solar collector systems. Elbreki et al. (2016) shows how the thermal and electric efficiencies present an opposite response to the design and operative parameters. Some recent review works (Al-Waeli

\footnotetext{
* Corresponding author

E-mail addresses: alessandro.cappelletti@unifi.it (A. Cappelletti), lucia.ceccherininelli@unifi.it (L. Ceccherini Nelli), alberto.reatti@unifi.it (A. Reatti).
} 


\section{Nomenclature}

$i \quad$ incident angle [Deg]

A capturing area [m]

$\mathrm{R}$ rotation angle [Deg]

BIPV building integrated photovoltaics

CPVT concentrated photovoltaic thermal

CPV concentrated photovoltaic

$\mathrm{DR}_{\mathrm{w}} \quad$ direct radiation

ORC Organic Rankine Cycle

NZEB nearly zero-energy buildings

PV photovoltaic

PVT photovoltaic thermal

\section{Greek symbol}

$\beta \quad$ surface tilt, angle [Deg]

$\beta_{a} \quad$ axis tilt, angle [Deg]

$\gamma \quad$ surface azimuth, angle [Deg]

$\gamma_{a}$ axis azimuth, angle [Deg]

$\gamma_{s} \quad$ solar azimuth, angle [Deg]

$\theta_{z} \quad$ zenith angle, angle [Deg]

$\eta_{\text {inv }} \quad$ inverter efficiency

$\eta_{p v} \quad$ cell efficiency

$\eta_{t} \quad$ thermal efficiency et al., 2017; Lamnatou and Chemisana, 2017; Sathe and Dhoble, 2017) analyzed over two hundred devices and researchers. The results emphasize that many innovative PVT and CPVT solutions have been developed in the last decades, but only a small number of them are commercially available.

For many years, active solar technologies have been intended as mechanical systems mounted on buildings, just utilized for power generation only. In a few cases, the proposed solutions make interiors more comfortable, however, seldom their design and their architectural integration in the building structures have been considered. The primary installation option for a solar device is the flat panel, but this solution results in a low integration with the building.

There are some studies (Good et al., 2015; Norton et al., 2011; Visa and Duta, 2016) where different solutions are proposed to achieve integration between devices buildings. These solutions are static, so their performances are limited (Bowden et al., 1994; Rabl, 1976; Yoshino et al., 1997, 1994). Very often, PVs systems have been designed aiming to achieve the maximum energy harvesting from sun power simply by installing standard flat panels on the building roofs and façades. Building-integrated photovoltaic (BIPV) are solutions, that can be used as a construction material, the system becomes part of the building envelope, architectural solutions for designers, maximizing the energy building performance, and reducing installation costs. CPVT systems can be applied for the building integration giving not only electric but also the thermal contribution, for this reason it is important to study new technical solutions for designers to give them the opportunity to use hybrid systems in the architectural contest without losing aesthetic attractiveness or reducing solar system power generation capability. This can be achieved by paying attention to the project design, by planning the integration of active solar devices since the very early stage of the architectural process, and by improving the architectural integration quality and flexibility of active solar products and devices. Small size solar concentrators are not largely investigated in literature; therefore, experimental results are seldom available on this kind of devices. Data of experimental tests confirm a high-efficiency operation of the proposed small size solar concentrator. The integration of semiparabolic concentrator with natural convection cooling has been recently proposed (Piratheepan and Anderson, 2017, 2015). Wu et al. (2016) presents a solution for the management of sunlight with a lightweight static concentrating device, installable on façades or windows. The device uses a thermotropic layer to reduce the flux on sunlight. Parasol device in linear Fresnel configuration (Chemisana, 2011; Chemisana and Rosell, 2011) permits to obtain two benefits, which are shading and electric power generation. The Janus PVT collector (Buonomano et al., 2013a,b, 2016; Calise and Vanoli, 2012) adjoin a PV panel with a roll bond, where the electric efficiency is about $12 \%$ and constant. A solar concentrator can result in a large component number, which can be limited by a proper design to reduce its cost (Whitfield et al., 1999). Ji et al. (2012) and Li et al. (2011) investigate the cell efficiency, confirming that monocrystalline cells work better than GaAs cells at a lower concentrating factor. A spectral filter (Jiang et al., 2010; Otanicar et al., 2015) permits to move the heat recovery on a different device. The reflective properties of aluminum foils and sheets showed that aluminum foil results in high specular reflectances (Kostic et al., 2010). A high efficiency in a CPV could be carried out if the concentrating mirror or lens produces a uniform solar flux on the PV cells. Meller and Kribus (2013) propose some solutions based on the kaleidoscope homogenizer concept. However, the varying shading situations reduce the kaleidoscope optical efficiency. Water desalination can take advantage of the CPV (Mittelman et al., 2009, 2007) but the cost is high and the operative temperature over $100^{\circ} \mathrm{C}$ is an important issue for the durability. Another application of CPVs is as a desiccant Air Handling Units where these devices contribute to a significant energy need reduction (Calise et al., 2014; Calise and Vanoli, 2012). The limit on PV cell working temperature prevents the use of collectors with high concentration factors. Some researchers (Kosmadakis et al., 2011; Tourkov and Schaefer, 2015) proposes the combination of CPV with ORC cycles to increase the performance and the economic advances.

Rosell et al. (2005) utilizes an electro-thermal linear CPV based on Fresnel lenses with a point focus, resulting in $60 \%$ total efficiency but the proposed device cannot be integrated into any building structure as any point focus solar concentrators because these devices require two axes solar tracking systems. Linear-focus solar concentrators, as shown in this paper, are suitable for integration in building structure but this has never be considered because most of the proposed linear focus solutions have very-large parabolic mirrors and most of them have a focus far away from the parabolic mirror surface. One example is CHAPS (Combined Heat And Power Solar), one of the most investigated CPVT devices (Coventry, 2005; Quaia et al., 2012), which is based on a linear concentrator with one-axis tracking and in-house manufactured cell. This device results in an excellent overall performance but the parabolic mirror has a two-meter width and nearly ten meters long and has the focus more than one meter outside the parabolic mirror surface. The experimental tests show the maximum efficiency is as high as $69 \%$, where $58 \%$ is the contribution of thermal output and $11 \%$ is given by the generated electrical power. The sizes of this device allow for its mounting on a building roof, but completely prevent its integration with the building structure.

This paper presents a small-size parabolic mirror solar concentrator where the linear solar focus is close to the parabolic mirror and inside the parabolic mirror cross-section. This solution makes the proposed devices suitable for building integration. The paper also presents several examples of possible building integration of arrays based on the proposed solar concentrator. The described small size solar concentrator is very suitable for building integration and easily mountable in many parts of a building, such as a roof, and facades (Good et al., 2015; Norton et al., 2011; Piratheepan and Anderson, 2017). Studies, presented in this paper, develop the design concept of prefabricated innovative shading devices, incorporating a series of linear semi-parabolic concentrator with a monoaxial sun tracking system as a solar 
shading system, consisting of vertical brises Soleil. Finally, practical consideration of the overall electrical and thermal energy generated by the proposed solar concentrator are given. These derivations are based on data achieved by experimental test on some solar concentrator prototypes (Cappelletti et al., 2016, 2015a, 2015b; Reatti and Beltramini, 2008; Serri et al., 2009; Catelani et al., 2016; Reatti et al., 2017).

The significance of the paper is that it introduces an innovative solution, which makes feasible the architectural integration of an electro-thermal solar concentrator.

Thanks to the simultaneous production of electrical and thermal power, the solar concentrator shows an excellent potential in the field of building constructions. It is particularly suitable for applications in farms, solar greenhouses, small industries, hotels, resorts, sports centers (changing room, swimming pool, etc.), beauty centers and SPAs.

The challenge is to realize multifunctional façade systems, through a multidisciplinary approach, involving, in both new and existing building stock, several items such as the architectural project, electrical and mechanical design, functionality and technical issues, economic issues related to cost optimization of industrial production processes, market placement and the return of the investment.

\section{Solar concentrator description}

The prototype of the solar concentrator module shown in Fig. 1 has been built up by CREAR (Centro Interdipartimentale di Ricerca per le Energie Alternative e Rinnovabili) and consists of four identical smallsize semi-parabolic units $(\mathrm{h} \times \mathrm{b} \times \mathrm{p}=170 \times 310 \times 1930 \mathrm{~mm})$. Fig. 2 shows a cross section of the prototype where $b=310 \mathrm{~mm}$ is each parabolic mirror aperture, $d$ is the distance among two adjacent mirrors and $L$ is the overall length of the considered configuration. This section also shows installation results in a very low height $(\mathrm{H}=170 \mathrm{~mm})$. As shown in Fig. 3, one of the main innovations of this concentrator is that the parabolic mirror has been designed and shaped so that the parabola focus is internal to the mirror cross-section. The receiver is located near one of the upper edge of the concentrator, with the cell facing the mirror at $45^{\circ}$ angle.

The combination of the mirror and the cell size results in a concentrator with a nominal concentration factor of $20 x$. The device results in a linear focus with the same length of the parabolic mirror but with a width 20 times smaller than the parabola. The sun tracking requires rotation around only one axis to keep the direct radiation solar rays perpendicular to the flat upper face of the receiver, so that they can be focused in the solar receiver where PV cells are mounted.

One more innovation is given by the solar receiver, which has been specifically designed for this application. The receiver is constituted by an aluminum profile where PV mono-crystalline cell strings are mounted. The aluminum profile is provided with two pipes, where a fluid (water) passes through and recovers the heat, which is given by the solar power not converted into electricity by PV cells (Cappelletti et al., 2016, 2015a, 2015b; Reatti et al., 2017; Reatti and Beltramini, 2008; Serri et al., 2009). This allows for both solar cells operating temperature control (Catelani et al., 2016; Reatti et al., 2017) and thermal energy recovery. The recovered thermal energy can be usefully utilized for all those applications requiring heat (Linderman et al., 2012).

The principal goal is to design a technological device that is easy to integrate in many different building typologies, like a standard brisesoleil. This provides new sustainable value to a classical shading solution. From the very begging of the design phase it has been assumed that the concentrator device should not appear as a facility system. Rather, the design concept was that the active shading device should interact with architecture, representing a benefit also from an aesthetical point of view. The possibility to use the linear element materials facilitates the dialogue with the building and the environment around. The device dimensions nearly the same (sometimes a little bit larger) of those of many shading systems already existing in the market, in this way the device can characterize the architecture looking fully integrated into the building.

The paper evaluates the energy performance of a device that includes all dimensional, functional elements and the architectural aspects; this activity is performed by an in-house developed numerical tool. The investigation considers two arrangements on the façade: horizonal and vertical. The results include performance, technicaleconomical comparison with the flat panels and some architectural suggestion for a better installation.

\section{Shading devices integration with the PVT concentrator}

An exciting installation option is to include the proposed device into innovative multifunction building shading solutions by integrating the solar power generator into a structure, which also provides the building shading. In such a case, the PV and solar thermal collectors become parts of the building shading elements, replace building elements and do not require extra investments. The overall costs are reduced because the same device provides both shading and electrical and thermal power generation.

The very early phases of the design process are crucial for such a solution: all the components must be considered for each single function they are called to perform and cannot be treated as separate components, which can be simply added once the building design is completed.

The control of the amount of sunlight admitted inside a building is a fundamental factor to be evaluated, and the possibility to reduce overheating and control-shading impact inside buildings is significant, mainly if an active solar system is utilized to do this.

In warm, sunny climates, especially in summer, the excess of solar radiation requires high duties to any cooling system, and this results in increased power consumption. During this season, the use of shading devices is crucial for the building energy management because external shading systems are excellent to prevent unwanted solar overheating. In cold and temperate climates winter sun can contribute to a passive building heating. Here, the amount of solar energy useful for interior heating is optimized by an appropriate matching among the needs of heating and those of diffuse natural illumination. Integration in the architecture of concentrator PVT modules can make the solar power generator also a good shading device, reducing building heat peaks, lowering the energy spent on cooling and improving natural daylighting.

Moreover, the integration of the concentrator system can provide an interesting and exclusive design.

This approach shows several advantages, providing interesting

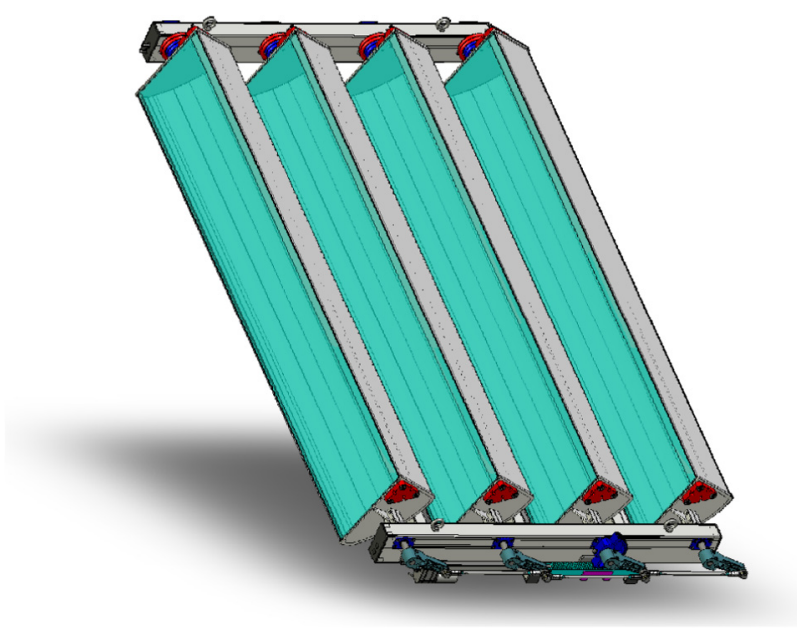

Fig. 1. Entire view of the modular solar concentrator. 


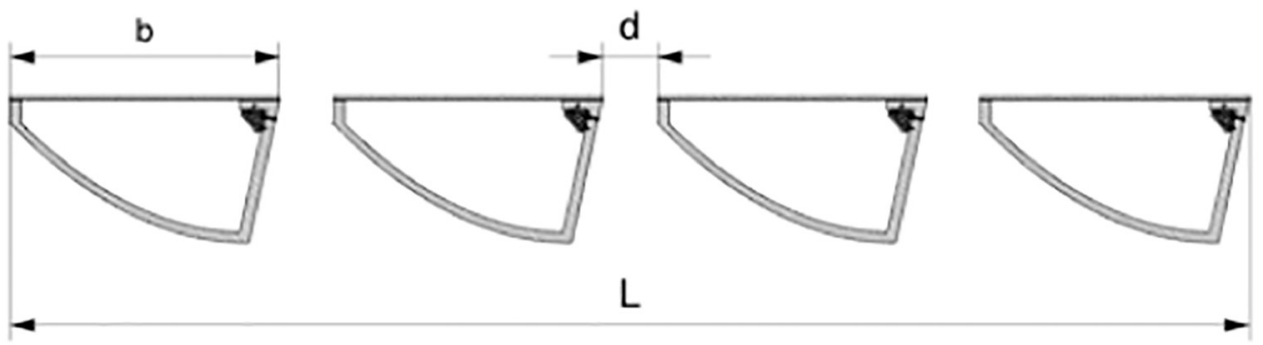

Fig. 2. Cross section of a combination of four parabolic mirrors, where $d$ is between two adjacent devices, $b$ is each parabola aperture, and $L$ is the overall length of the set-up.

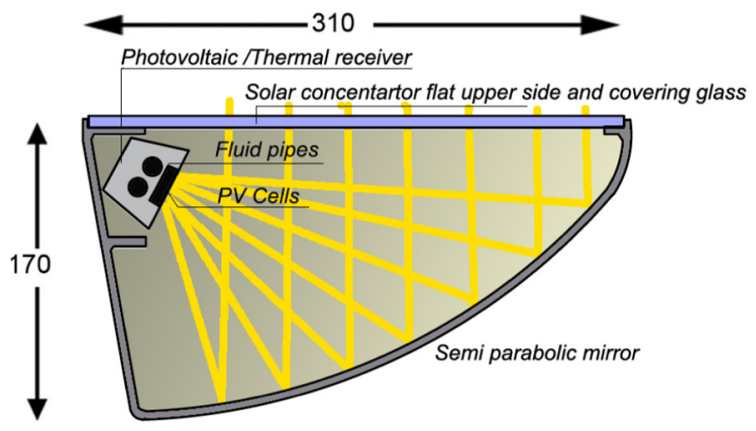

Fig. 3. Cross-section of the semi-parabolic PV/T solar concentrator: the sizes $[\mathrm{mm}]$ and component description.

architectural solutions and many benefits. However, to reach the best energy solution it is necessary to:

1. evaluate different shading strategies with different materials, such as opaque and transparent shading elements (this allows the best building shading factor to be achieved);

2. optimize the integration of one or more concentrator elements into the shading devices (e.g., both vertical and horizontal positioning must be considered);

3. optimize the number of concentrators needed to have a reasonable electric and thermal power generation.

Some examples of systems realized with vertical louver blinds are shown in Figs. 4 and 5; these figures show simulations of possible mounting of the proposed solar concentrator on existing buildings and they also show how their integration is possible. They consists of many essential vertical aluminum elements, alternated with PV/T shading devices, connected at the bottom with chains to an aluminum line along, where shading devices carriers and incorporate movable mechanisms. Vertical blind headrails are made of extruded aluminum, which is either anodized or painted. Sensors provide the correct suntracking and the sun position is followed during the daytime to get the maximum thermal and electric power generation.

In the examples shown in Figs. 4 and 5, arrays of parabolic mirrors built with an aluminum body each with a $310 \mathrm{~mm}$ width and $170 \mathrm{~mm}$ height and $3000 \mathrm{~mm}$ length (like building height between floors) is considered. Other size modules can be adopted.

As shown in Fig. 6, the integration of arrays of solar shading concentrators is also achieved by using alternated horizontal louvers. These are placed in various ways, shapes, depths, and heights depending on parameters like the installation latitude. Metal louvers can provide outstanding control of daylight and reduce solar heat gains. They can be either extruded or fabricated and can also be perforated. Horizontally movable louvers are often chosen for application in building utilized for offices, schools and sports facilities. Here, the solar concentrator can be mixed with perforated metal louvers so that a precise control of heat amount and light entering the building is achieved. It also affects the quality of the outward view. Metal louver systems can be used either in anodized aluminum polyester powder aluminum to a RAL color or stainless steel.

To understand how a shading system helps to reduce the inlet sunlight some simulations are shown. This study is carried out by the VELUX Daylight Visualizer; it is a professional lighting simulation tool for the analysis of daylight conditions in buildings. The tool calculates luminous distribution using the ray-tracing process; it was validated against CIE 171:2006 test cases from the developers and it is used from many studies (Acosta et al., 2015; Iommi, 2016; Labayrade et al., 2009; Soori and Vishwas, 2013) where its capabilities were comparted with other similar tools.

This type of analysis must be done before realization of the building

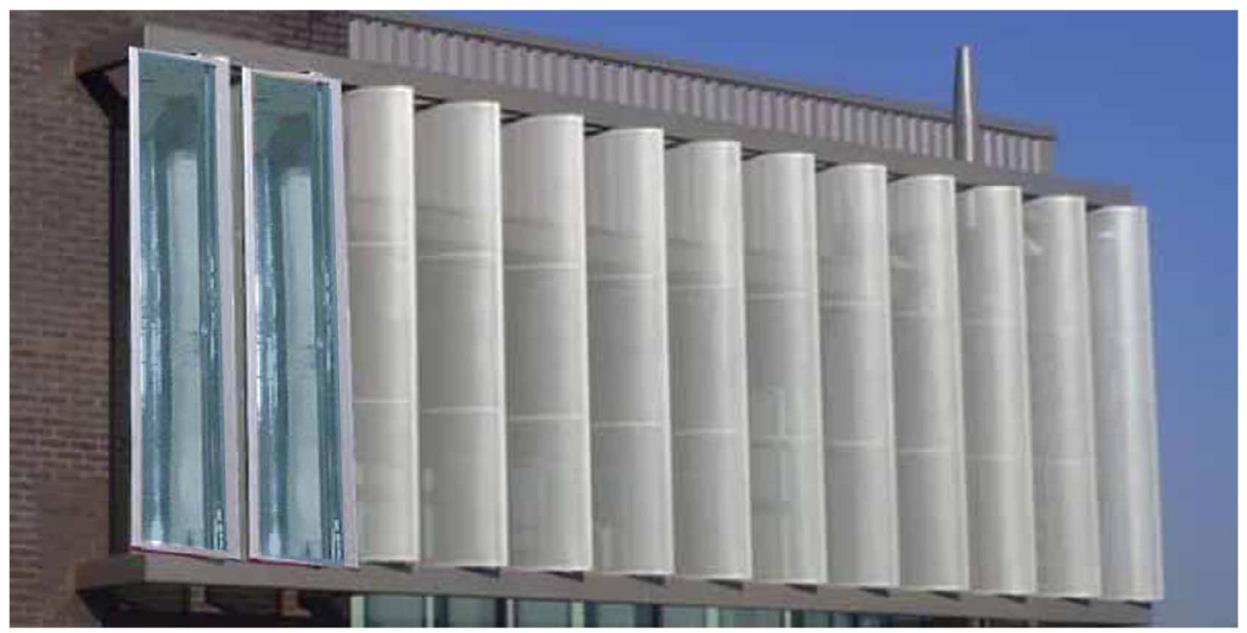

Fig. 4. Simulation of vertical aluminum shading devices alternated with $\mathrm{PV} / \mathrm{T}$ integrated devices. 


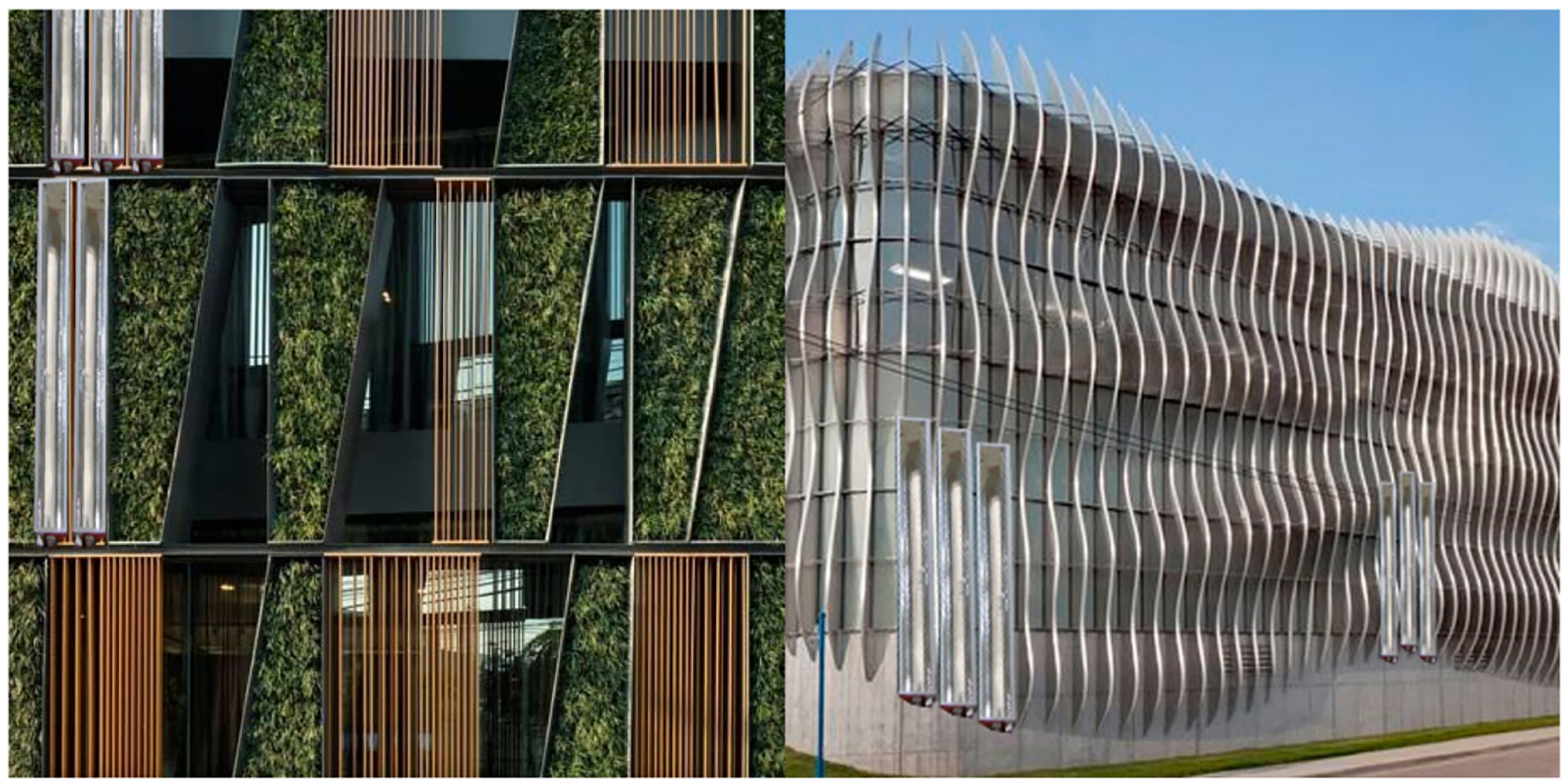

Fig. 5. Simulation of a solar concentrator device integrated into architecture with vertical shading louvers.

design to set the number of (horizontal or vertical) shading devices that should be used once the specific characteristics of the rooms and building are known. The assessment period should ideally be a full year, so that the seasonal variation in daylight is captured, and the time step should be small enough to capture the observed short-term variation in daylight.

This work studies a standard room of $4500 \times 6000 \mathrm{~mm}$ with three windows, south oriented in Florence in Italy. The example building considers a double skin façade consisting of shading devices $(3000 \mathrm{~mm}$ length), integrated with the solar concentrator system, separated $50 \mathrm{~cm}$ from the building with spaced elements of 300, 600 and $900 \mathrm{~mm}$ $\left(d_{n}=d / b=1,2\right.$ and 3), placed horizontally or vertically.

The analysis is limited to two months: June and December because these are the reference months with the highest insolation and the lowest of the whole year.

Figs. 7-10 show the illuminance's distribution on the surfaces (measured in LUX) in the room, looking the three windows. The illuminance is the total luminous flux on a surface, and it is referred to the illuminated object. The reference cases are where no shading devicse are installed as shown in Fig. 7.

The result of the luminance analysis shows that the horizontal solution offers a better comfort in term of natural lighting than the vertical one, especially in winter, because the vertical solution, with spaced elements of $30 \mathrm{~cm}$, offers an insufficient lighting gradient to guarantee optimal comfort standards in the interior surfaces. With a larger distance than $30 \mathrm{~cm}$ between the elements, devices offer a good winter shading solution but an excessive discomfort during summer months, creating overheating of the glazing surface. As a result, this latter solution is not considered performing enough.

As a final conclusion, the horizontal assembly of $30 \mathrm{~cm}$ spaced sunshade elements is preferable and allows good indoor lighting behavior both during winter and summer months.
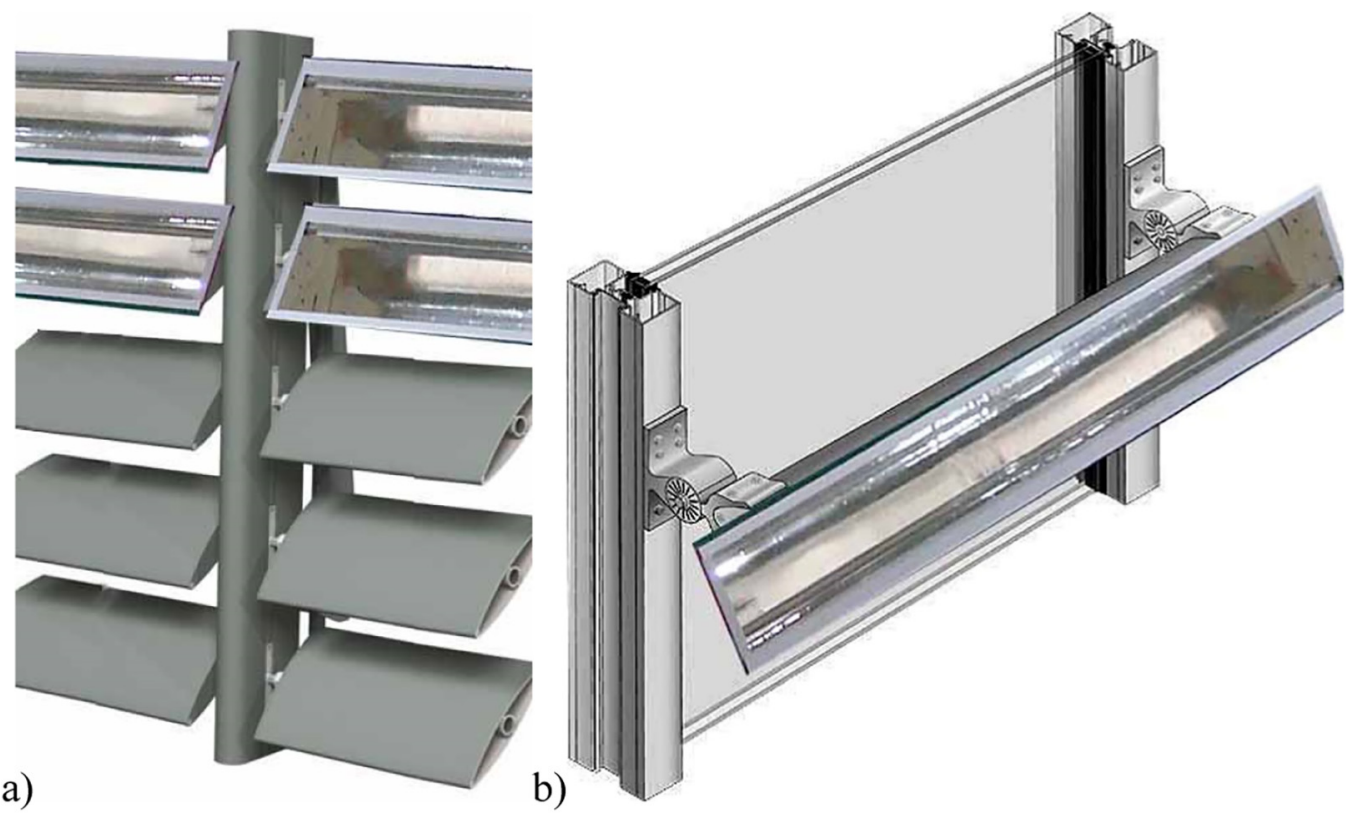

Fig. 6. Axonometric views of a simulated system combined with the solar concentrator, in horizontal as sunscreen. 


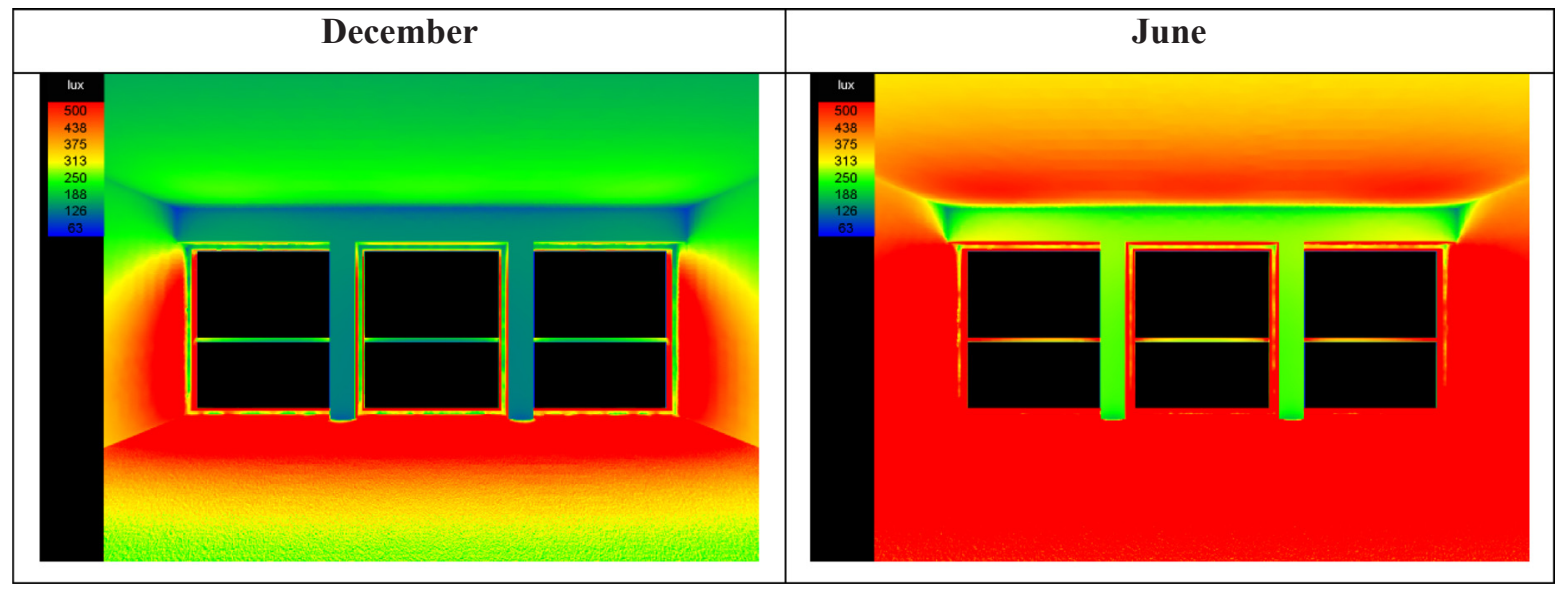

Fig. 7. Illuminance maps [LUX] without shading devices.

\section{Description of the analysis method}

The performance analysis considered in this section is based on a numerical approach supported by some information from previous works. The method starts with an algebraic study for the evaluation of Sun position and device motion. With the information how the receiver works, the study calculates the received energy and after known the efficiency it evaluates the energy production.

The investigated device is mounted with a particular tilt angle and tracks the sun only along one axis so there is always an incidence angle $i$ between the sun direction and the concentrator surface (Cappelletti et al., 2016, 2015a). For a correct evaluation of this angle, the main method was proposed by Marion and Dobos (2013) who first evaluated the correct rotation angle $R$ to line up the collector with the sun (Eqs. (1)-(3)). The $i$ angle is calculated by Eqs. (4)-(6), given as follows (quantities utilized are shown in Fig. 11):

$R=\tan ^{-1} X+\psi$

where:

$X=\frac{\sin \vartheta_{Z} \sin \left(\gamma_{s}-\gamma_{a}\right)}{\sin \vartheta_{Z} \cos \left(\gamma_{s}-\gamma_{a}\right) \sin \beta_{a}+\cos \vartheta_{Z} \cos \beta_{a}}$

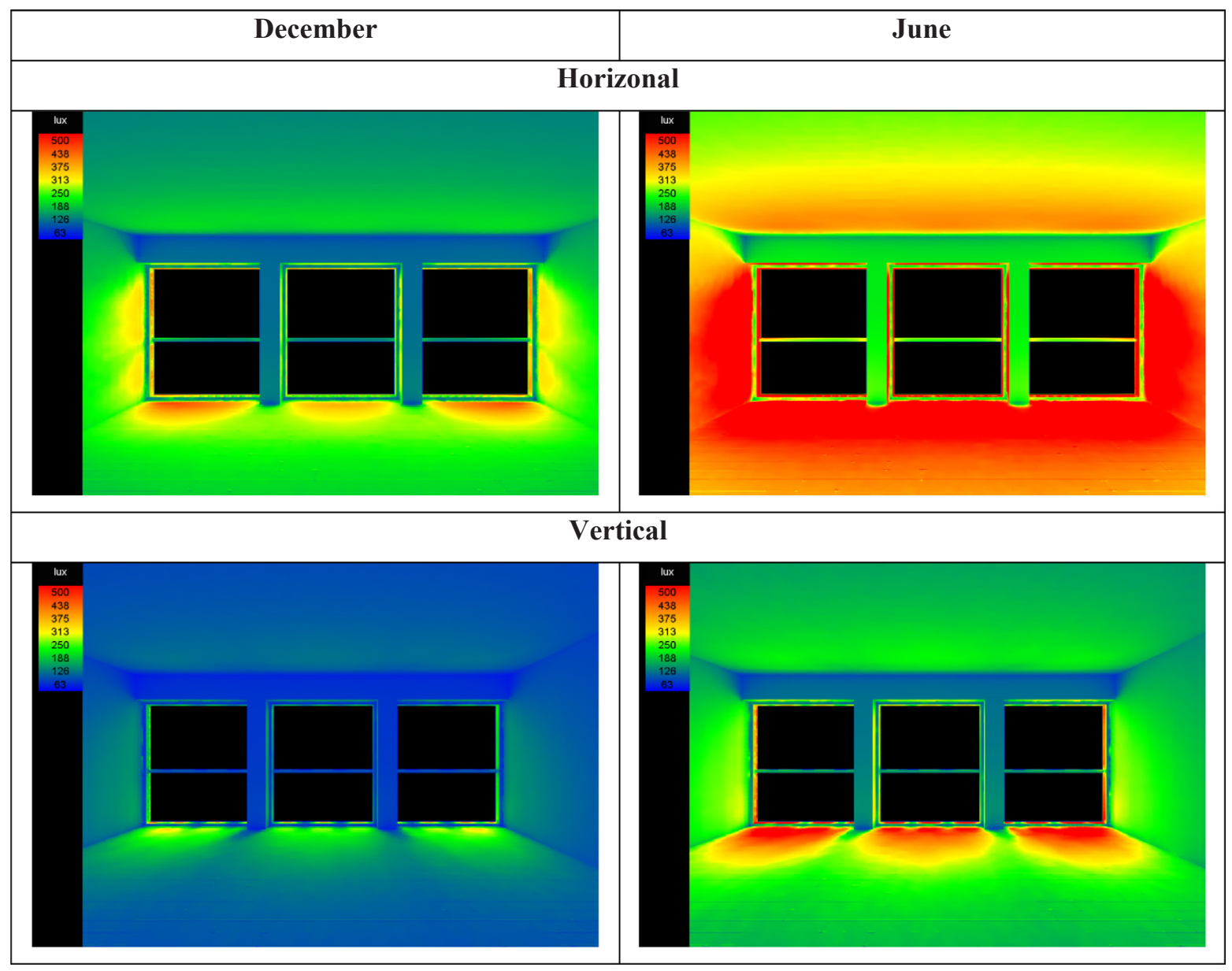

Fig. 8. Illuminance maps [LUX] with device at $300 \mathrm{~mm}$. 


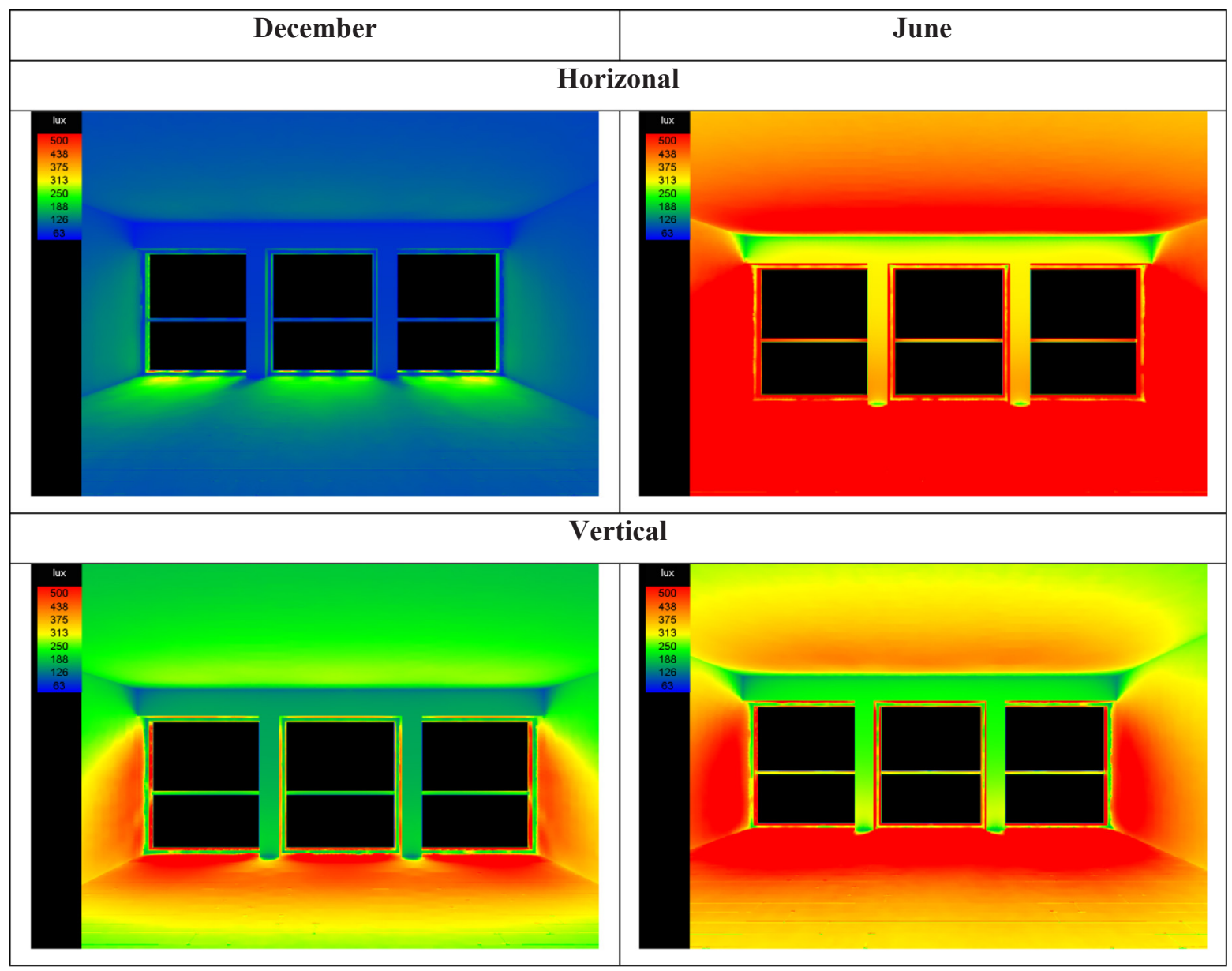

Fig. 9. Illuminance maps [LUX] with device at $600 \mathrm{~mm}$.

$\psi= \begin{cases}0^{\circ} & \text { if } X=0^{\circ} \text {; or; or if } X<0^{\circ} \text { and } \gamma_{s}-\gamma_{a}<0^{\circ} \\ 180^{\circ} & \text { if } X<0^{\circ} \text { and } \gamma_{s}-\gamma_{a}>0^{\circ} \\ -180^{\circ} & \text { if } X>0^{\circ} \text { and } \gamma_{s}-\gamma_{a}<0^{\circ}\end{cases}$

The angle $R$ range is limited in the $-45^{\circ}$ to $+45^{\circ}$ range by the device construction limitations.

$\beta=\cos ^{-1}\left(\cos R \cos \beta_{a}\right)$

$\gamma=\gamma_{a}+\sin ^{-1}\left(\frac{\sin R}{\sin \beta}\right)$

$i=\cos ^{-1}\left[\cos \beta \cos \vartheta_{Z}+\sin \beta \cos \vartheta_{Z} \cos \left(\gamma_{s}-\gamma\right)\right]$

Fig. 12 shows the solar power (direct component) captured by the receiver as a function of the incident angle evaluated under clear sky conditions, and derived by a ray-trays analysis performed in previous work (Cappelletti et al., 2016). This analysis is based on the following assumptions: $1000 \mathrm{~W} / \mathrm{m}^{2}$ input solar radiation, an incident power as high as $580 \mathrm{~W}$ when $i=0^{\circ}$ and as low as $350 \mathrm{~W}$ at $i=45^{\circ}$.

All the fixed tilt, single axis sun tracking solar concentrators are affected by the so-called end-wall effect (Cappelletti et al., 2015b; Serri et al., 2009; Weinstock and Appelbaum, 2004). Actually the bottom edge of the parabola, which has a height $h_{\text {parabola, }}$ shadows a certain length $l_{\text {shadow }}$ of the solar collector, which depends on $i$ as follows

$l_{\text {shadow }}=2 h_{\text {parabola }} \sin (i)$

As consequence, the actual receiving area $A$ is a function of $i$ as follows

$A(i)=w_{\text {focus }} *\left(l_{\text {receiver }}-l_{\text {shadow }}\right)$ where $w_{\text {focus }}$ is the linear focus width.

To evaluate the effect of weather conditions (no-clear sky conditions) on the captured energy, the study uses the records of LaMMA's ("Consorzio LAMMA. Laboratorio di Monitoraggio e Modellistica Ambientale per lo sviluppo sostenibile - Laboratory for Meteorology and Environmental Modelling," 2016) weather station for the 2016 year. The data set utilized include the total solar radiation $T R_{\text {lamma }}$ and diffuse radiation $D R_{\text {lamma }}$ on a horizontal plane evaluated every $15 \mathrm{~min}$. This effect is managed by a mitigation factor $K_{w}$ evaluated by equation 9 , comparing the acquired data with the theoretical clean-sky value $D D R_{\text {clean-sky, }}$, evaluated at ground.

$K_{w}=\frac{T R_{L A M M A}-D R_{L A M M A}}{D D R_{\text {clean }- \text { sky }}}$

The difference between $T R_{\text {lamma }}$ and $D R_{\text {lamma }}$ allows the derivations of the direct radiation $D D R_{\text {clean-sky }}$ (which is the part of solar radiation useful for power generation in solar concentrators).

This device is focused on producing hot water for hot running water, with an about $50{ }^{\circ} \mathrm{C}$ temperature. The thermal efficiency, $\eta_{t}$, in this condition, is evaluated from previous test campaign on the prototype where a $64 \%$ value is achieved with a delta temperature from the inlet and to the outlet of $2-3{ }^{\circ} \mathrm{C}$, however it is lower compared with a flat panel (over 7\%). This thermal efficiency is similar to other devices (Calise et al., 2012; Coventry, 2005; Vivar et al., 2012): in all these devices the close-packed shape of the receiver reduces the thermal dissipations. The problem is on PV cells side because the domestic hot water must be close to $50^{\circ}$, which is a temperature value very close to the higher PV cell operative limit.

The cell efficiency $\eta_{p v}$, is about 18-19\% (Cole et al., 2006; Heasman 


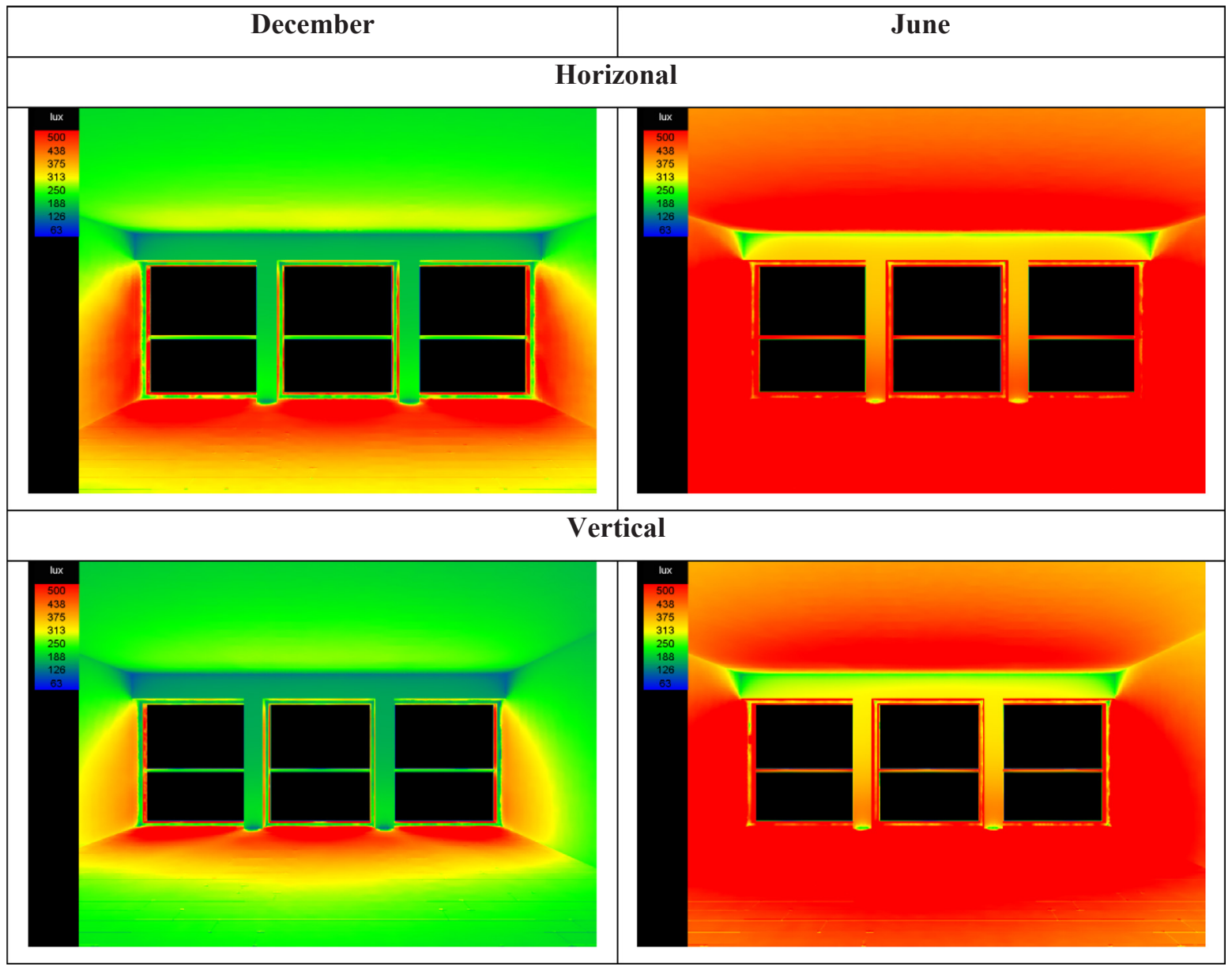

Fig. 10. Illuminance maps [LUX] with device at $900 \mathrm{~mm}$.

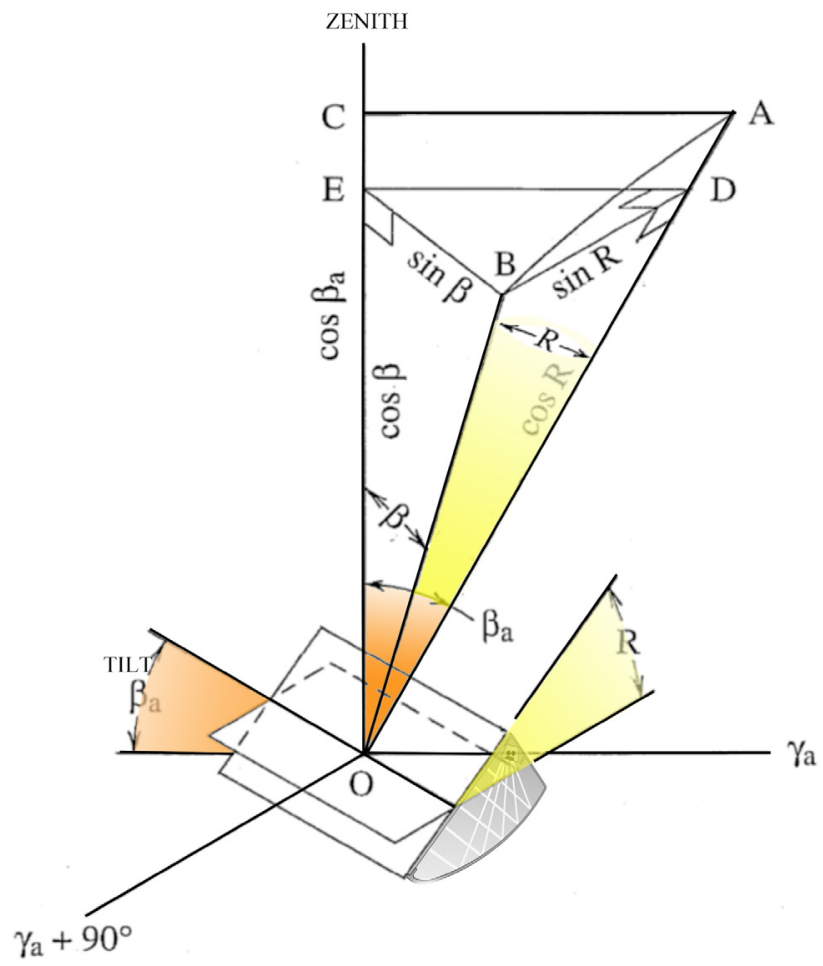

Fig. 11. Geometry for one-axis tracking surface.

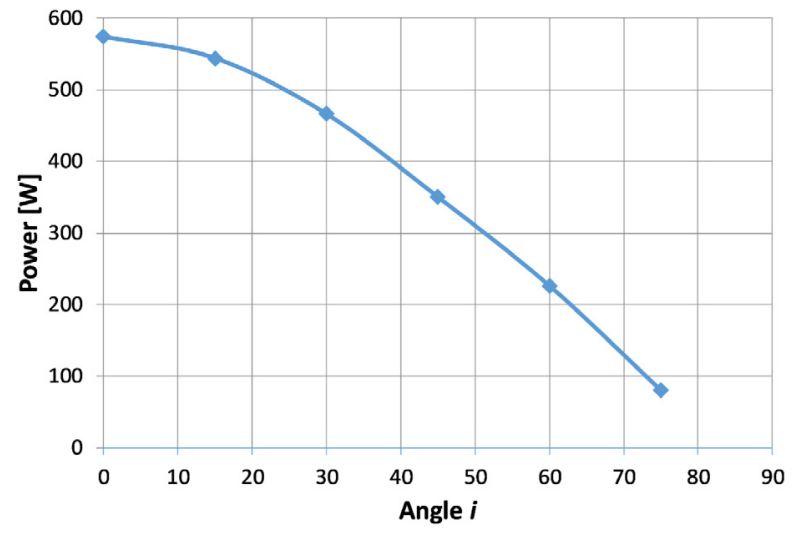

Fig. 12. Solar power on the receiver vs angle $i$.

et al., 2011, 2007) at ambient temperature but at the $50^{\circ} \mathrm{C}$ the efficiency decrease to $16-17 \%$ (Skoplaki and Palyvos, 2009). The inverter efficiency, $\eta_{i n v}$, is about $90 \%$ (Kribus et al., 2006).

Thermal Power $=\eta_{t}{ }^{*} K_{w}{ }^{*} D R(i)_{\text {clean-sky }}{ }^{*} A(i)$

Electric Power $=\eta_{p v}{ }^{*} \eta_{i n v}{ }^{*} K_{w}{ }^{*} D R(i)_{\text {clean-sky }}{ }^{*} A(i)$

This model implemented in a Python 3.6 script (Python, 2016), can provide a semi-dynamic calculation of energy captured by the receiver during a solar year. The script utilizes Pysolar library (Pysolar, 2013) for the evaluation of angles $\theta_{z}$ and $\gamma_{s}$, using the algorithm from Reda and Andreas (2004).

The library provides the direct solar radiation values under clean 


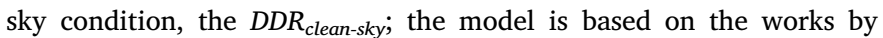
Bishop et al. (1997), Masters (2004).

The calculation runs on every minute of a day, in theory, 1440 timesteps/day, it evaluates the actual captured solar radiation and after it counts the thermal and electric energy using Eqs. (10) and (11). The results are aggregated to evaluate the energy production in a specific day and after in the reference year (2016).

\section{Solar concentrator analysis and its results}

This section, in its first part, presents an analysis of the effects of mutual shadowing on the proposed solar concentrator referring to two cases: horizontal and vertical mounting of several parabolic mirrors on building facades to constitute PVT arrays. In the second part of this section a techno-economical comparison among the proposed solution and plants based on standard flat PV panels is given.

\subsection{Power generation and efficiency}

The numerical procedure presented in the previous section is applied to a hypothetic installation in Florence, Italy, (lat: $43.8016626^{\circ}$ long: $11.2558136^{\circ}$ ) with three azimuth angles: $0^{\circ}, 45^{\circ}, 90^{\circ}$ and it considers both the horizontal and the vertical solution.

Fig. 13 shows the estimated electrical and thermal power generated by a single parabola operated with a $0^{\circ}$ tilt angle (Horizontal operation so Sun Altitude tracking) and the case with a single parabola operated with a $90^{\circ}$ tilt angle (Vertical operation so East-West tracking). The comparison of the plots shown in Fig. 13 shows that the energy generation is higher when the solar concentrator operates with a $0^{\circ}$ tilt. A South oriented device, mounted as shown in Fig. 5, and tracking the sun height, generates $115 \mathrm{kWh}$ /year of the electric energy and $512 \mathrm{kWh} /$ year of thermal energy. If the device is operated with a $\pm 45^{\circ}$ azimuth angle (SE or SW orientation) the power generated reductions is as low as $6 \%$, while the reduction increases to more than $26 \%$ when the concentrator is West or East oriented that is a $\pm 90^{\circ}$ azimuth angle operation, respectively.

When the solar concentrator is vertically mounted, as shown in Fig. 4, and, therefore, tracks the Sun from East to West during the daytime, the power generation reduces nearly linearly with the azimuth angle: the reduction is as high as $12.5 \%$ with a $\pm 45^{\circ}$ azimuth and increases to $21 \%$ when the azimuth reaches $\pm 90^{\circ}$.

In previous considerations, the mutual shading effect has not been considered because a single parabolic solar concentrator power generation has been considered. The same would be for devices, which have a relative distance as high as infinite, which is an unrealistic case. Therefore, the so-called cut-off condition must be considered. This condition occurs when a parabolic mirror is half shaded by the parabolic mirror next to it and placed on the sun side. It is assumed that the solar concentrator does not produce electric energy under the cut-off condition. Fig. 14 shows the plots of the energy production and the distance $d$ in comparison to an infinite distance case. As Fig. 14 shows, the vertical installation (East-to-West sun tracking), is more affected by mutual-shading than the horizontal installation (sun height tracking). When the distance among two adjacent concentrators normalized concerning the concentrator parabola aperture is as high as $d_{n}=d$ / $b=0.67(d=200 \mathrm{~mm})$ the power generated is $70 \%$ of the power generated by not-shaded solar concentrator. When this distance increases to $d_{n}=d / b=1$ (that is $d=300 \mathrm{~mm}$ ) the energy produced increases to $74 \%$ of the case where solar concentrators are not shadowed. This allows an $81 \mathrm{kWh}$ /year power generation to be calculated for south oriented, 3-meter long parabola. Over $500 \mathrm{~mm}$ the increasing is limited and at $d_{n}=d / b=2$ the available energy level is constant. As shown in Fig. 14, shading has a limited effect on horizontally mounted solar concentrators. At the maximal sun altitude for Florence (the sun azimuth is $70^{\circ}$ at 12 of June 21) for a relative distance $d_{n}=d / b=2$ $(d=600 \mathrm{~mm})$ distance, results in no shading effect; when $d_{n}=d / b=1$
( $d=300 \mathrm{~mm}$ ) the power generated is $97 \%$ of the power generated by not-shaded concentrators, at $d_{n}=d / b=2(600 \mathrm{~mm})$ is very close to $100 \%$.

\subsection{Comparison with flat panels}

The flat panels are the most utilized devices in PV plants. Therefore a techno-economical comparison is carried out based on data shown in Table 1, which refers to $1 \mathrm{kWel}$ (Electrical $\mathrm{kW}$ ) for PV panel, for one thermal panel, for one sunscreen blade, and one CPV parabola.

The cost for the flat panel is obtained with a commercial analysis from some Italian (IES-Solare, 2017) and European (Gaëtan Masson et al., 2017; pvXchange Trading, 2017) sellers in October 2017. The occupied area for the flat panels is defined as the occupied plane surface including the distance between the panel that optimizes the mutual shading. At the Florence's (Italy) latitude, the occupied area is twice the receiving area.

The solar concentrator presented in this paper requires a piping system only slightly different from that of standard solar thermal flat panels, e.g. both standard flat panel, and the concentrator based systems require the same recirculation pump. One parabola shows a heat loss of only $0.012 \mathrm{~m}$ of heat in comparison to a $0.020 \mathrm{~m}$ of heat for a commercial flat thermal panel when the mass flow rate is about $0.0150 \mathrm{~kg} / \mathrm{s}$. When the solar concentrator is regarded as a PV device, the only significant aspect to be considered in comparison to standard flat panel plants is the presence of a flexible cable connection between the device and the building. This solution, however, can be realized with standard components and at low costs. Since the auxiliary plant's components are nearly the same, an economic comparison requires only device costs and energy production to be considered.

The comparison considers a plant constituted by ten parabolas (dimension: $310 \times 3000 \mathrm{~mm}$ ).

This configuration with a distance $d=300 \mathrm{~mm}$ occupies a $20 \mathrm{~m}^{2}$ surface on a building façade and produces, in Florence (Italy), about $1200 \mathrm{kWh} /$ year of electric power and $5000 \mathrm{kWh} /$ year of thermal power. To produce the same energy, a $1 \mathrm{kWel}$ peak power PV plant is needed along with three conventional flat thermal panels. The overall occupied surface of such a plant is as high as $32 \mathrm{~m}^{2}\left(16 \mathrm{~m}^{2}\right.$ for the PV panels and $16 \mathrm{~m}^{2}$ for the solar thermal panels).

As emphasized in Section 3, a $d_{n}=1$ is too close for shading because the illuminance is highly reduced, so a better solution could be to increase $d_{\mathrm{n}}$ to $2(d=600 \mathrm{~mm})$, this makes the same 10 devices cover about $27 \mathrm{~m}^{2}$, or have 6-7 devices if the same $18 \mathrm{~m}^{2}$ area is considered.

The presented solar concentrators require a large area but allow for a sunscreen on the façade to be achieved and do not require the roof to be occupied, which, then, keeps free for other installations.

A preliminary cost analysis of the presented device, see Table 2, determines $900 €$ commercial cost for a single parabola including the mounting structures and solar tracking system. Cost contributions are as follows: reflective parabola cost $375 €, \mathrm{CPV}$ receiver about $375 €$,

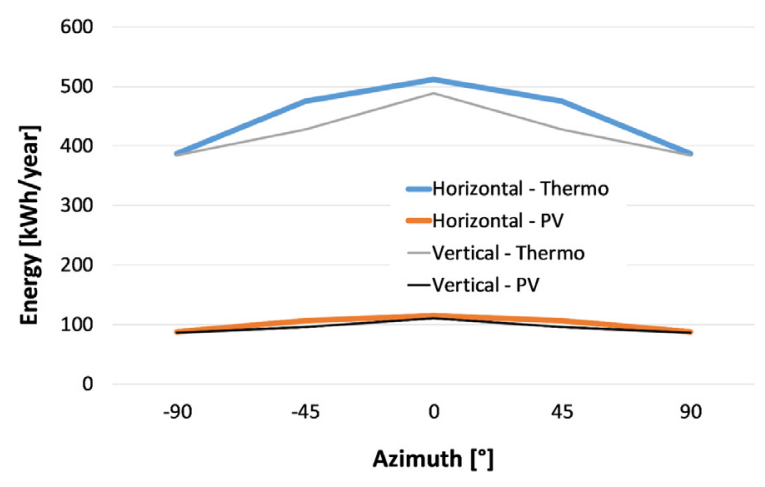

Fig. 13. Estimated thermal energy and electric energy production. 


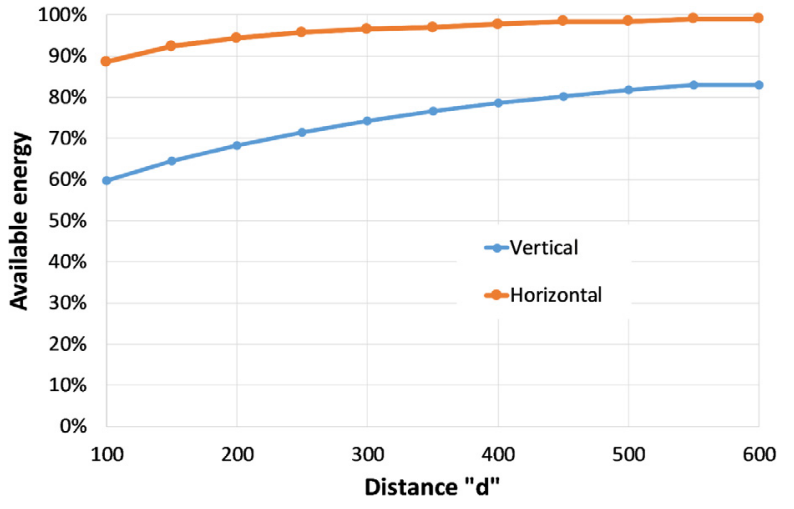

Fig. 14. Available energy as function of " $d$ " device distance.

support and movement systems about $150 €$.

A plant constituted by ten parabolas costs $9000 €$, but this device provides three features, which, otherwise, would require three different plants, one for any purpose: (a) the electric power generation is formed by PV plant with $1 \mathrm{~kW}$ of flat panel cost $1700 €$, (b) thermal power generation formed by 3 solar thermal flat panels for a cost toward 3000 $€$ and (c) shading sunscreens, which have an about $4800 €$ cost.

The resulting overall cost of this conventional system is, then, 9500 $€$, with the roof occupied by the hybrid system and not available for air conditioning devices or any other building facility.

This analysis permits to emphasize how the integration of solar active systems into architecture could be possible and the BIPV is an elegant solution for on-site self-generation of electricity and heat directly from the sun. When this system is also used for shading advantages are many as follows:

- BIPV or PVT materials replace conventional building element, including part of the roof and facades, for this reason, initial cost can be offset reducing money spent on construction materials and labor necessary to build them replaced by BIPV or PVT solar panels.

- Design, can be fully customized in size, kind of material and color and become part of the structure characterizing all design of the building.

- Modules can be a protection from sunlight and wind and rain.

Moreover, by focusing on the integration of a low concentration system, the critical issues concerning high prizes for materials and maintenance, easy deterioration and heat disposing are prevented.

\section{Conclusion}

Solar concentrators represent an interesting solution for building self-power generation and to support the zero-energy philosophy.

BIPV and PVT can be the optimal method of installing renewable energy systems in urban areas.

The difference between BIPV and PVT systems is that the first one is formed by standard PV module, with solar cells encapsulated on many various materials. Modules are connected in an electrical series to form a PV array. In the case of PVT, modules are larger, include the parabola
Table 2

Costs $[€]$ for $3 \mathrm{~m}$ parabola.

\begin{tabular}{lll}
\hline & Min & Max \\
\hline Refletive parabola & 330 & 420 \\
CPV Reveiver & 330 & 420 \\
Support \& movement & 140 & 160 \\
Total & 800 & 1000 \\
\hline
\end{tabular}

that can be sized in comparison with the latitude site. The architectural effect inside rooms, is the direct or diffuse sunlight that pass through the solar cells (BIPV) or through the parabolas (PVT) creating a shadowed facade. Windows, skylights, and facade shelves can be designed to increase daylighting performances in interior spaces. The PVT elements can be mixed with other building materials, such as: green walls, wood or metal shading devices, or integrated into the windows becoming solar shelf, very useful to bring light into the deeper parts of the building, commonly less lightened by direct solar radiation. The technology of both applications, maximize energy efficiency within the building energy demand or load of the entire energy, the solar devices can be optimized and holistically designed to reduce the building's energy demand for electric and thermal needs, as the weathering skin of the building generate electricity on site.

The system may act as an application effective in reducing direct heat gain and glare and it can bounce light as deeply into the space if it is helped by a clear ceiling and deflector. Exterior light shelves do not radiate as much heat into the space and this can help to reduce solar heat gain and cooling loads.

The following advantages of the design of low energy architecture are achieved:

- electric and thermal energy are simultaneous;

- daylight quality is enhanced;

- the need for artificial lighting and so reduce energy consumption is reduced;

- cooling loads are reduced;

- occupant comfort and productivity are increased;

- the design aesthetic is improved.

Solutions described in the present work, are based on two arrangements of a small size parabolic hybrid PV concentrator: horizontal and vertical positioning of the parabolic solar concentrators. The analysis presented in the paper shows that both the two arrangements result in a similar power generation, which is about $110 \mathrm{kWh} /$ year electrical power and $500 \mathrm{kWh} /$ year thermal power when facing south $\left(0^{\circ}\right.$ azimuth).

In conclusion, it is shown that the mutual shading results in $25 \%$ yearly power loss reduction for a vertical installation but keeps less than $5 \%$ for a horizontal device mounting.

The market for combined PV/ST systems is quite small compared to that of pure photovoltaic or solar thermal systems, but the number of commercially available products is expected to increase in the next decade. The increasing interest in PVT is probably, at least to a certain extent, driven by the increasing interest in energy efficient buildings worldwide and the possibility to achieve a better building integration.

Table 1

Comparison between different device: PV flat, thermal flat, presented CPV and suncreen.

\begin{tabular}{|c|c|c|c|c|}
\hline & $1 \mathrm{kWel}$ PV flat panel & One thermal flat panel & Presented CPV parabola & Sunscreen blade \\
\hline Electric energy production $[\mathrm{kWh} /$ year] & 1200 & - & 120 & - \\
\hline Thermal energy production [kWh/year] & - & 1700 & 500 & - \\
\hline Heat loss $[\mathrm{m}]$ & - & 0.020 & 0.012 & - \\
\hline Occupied area $\left[\mathrm{m}^{2}\right]$ Florence's latitude $\left(43.8016626^{\circ}\right)$ & 16 & 5.4 & 2 & 2 \\
\hline Cost $[€]$ & 1700 & 1000 & $800-1000$ & 480 \\
\hline
\end{tabular}


The choice among vertical or horizontal shielding systems use, must be made by the designer in the form of the shape and orientation of the building. Horizontal devices generally are used to shade a window or a glass façade during summer months and reflect sun rays avoiding overheating and are very useful to allow sunlight to get through the façade during the winter season; sunlight penetrates the rooms and get passive heating into the building. The horizontal shading device are used also like light shelves when they are positioned in the middle or the upper part of the window surface; they are very useful to control and reflect solar radiation to get light into the inner building rooms. Vertical devices are generally used for the east and west exposures to improve sunlight radiation during winter months; they also act as a windbreak.

The choice for the vertical or horizontal solution is not related to the energy production requirements but, rather, to building-related parameters, such as, shadowing and architectural integration.

The concentration devices, being thermally more efficient than the electrical point of view, are suitable for many buildings typologies such as: gyms, swimming pools, beauty SPAs, structures with seasonal opening such as bathhouse or campsites where there is a reasonable need of hot water production. The system can be equally efficient to produce electrical and thermal energy in isolated structures such as mountain refuges or on islands with stand-alone systems connected with batteries.

\section{Funding}

This work was supported by the Italian Ministry of the Environment (MATTM Ministero dell'Ambiente, del Territorio 291 e della Tutela del Mare) in 2012 under the grant named "POWER FROM THE SUN - codice 75 - Bando per il finanziamento di progetti di ricerca finalizzati ad interventi di efficienza energetica e all'utilizzo delle fonti di energia rinnovabile in aree urbane.

\section{References}

Acosta, I., Munoz, C., Campano, M.A., Navarro, J., 2015. Analysis of daylight factors and energy saving allowed by windows under overcast sky conditions. Renew. Energy 77, 194-207. http://dx.doi.org/10.1016/j.renene.2014.12.017.

Al-Waeli, A.H.A., Sopian, K., Kazem, H.A., Chaichan, M.T., 2017. Photovoltaic/thermal (PV/T) systems: Status and future prospects. Renew. Sustain. Energy Rev. 77, 109-130. http://dx.doi.org/10.1016/j.rser.2017.03.126.

Bishop, J.K.B., Rossow, W.B., Dutton, E.G., 1997. Surface solar irradiance from the international satellite cloud climatology project 1983-1991. J. Geophys. Res. Atmos. 102, 6883-6910. http://dx.doi.org/10.1029/96JD03865.

Bowden, S., Wenham, S.R., Dickinson, W.R., Green, M.A., 1994. High efficiency photovoltaic roof tiles with static concentrators. In: Proceedings of 1994 IEEE 1st World Conference on Photovoltaic Energy Conversion - WCPEC (A Joint Conference of PVSC, PVSEC and PSEC). IEEE, pp. 774-777. doi:http://dx.doi.org/10.1109/WCPEC. 1994.520074.

Buonomano, A., Calise, F., Dentice d'Accadia, M., Vanoli, L., 2013a. A novel solar trigeneration system based on concentrating photovoltaic/thermal collectors. Part 1 : Design and simulation model. Energy 61, 59-71. http://dx.doi.org/10.1016/j. energy.2013.02.009.

Buonomano, A., Calise, F., Palombo, A., 2013b. Solar heating and cooling systems by CPVT and ET solar collectors: a novel transient simulation model. Appl. Energy 103, 588-606. http://dx.doi.org/10.1016/j.apenergy.2012.10.023.

Buonomano, A., Calise, F., Vicidomini, M., 2016. Design, simulation and experimental investigation of a solar system based on PV panels and PVT collectors. Energies 9, 497. http://dx.doi.org/10.3390/en9070497.

Calise, F., Dentice d'Accadia, M., Roselli, C., Sasso, M., Tariello, F., 2014. Desiccant-based AHU interacting with a CPVT collector: Simulation of energy and environmental performance. Sol. Energy 103, 574-594. http://dx.doi.org/10.1016/j.solener.2013. 11.001.

Calise, F., Palombo, A., Vanoli, L., 2012. A finite-volume model of a parabolic trough photovoltaic/thermal collector: Energetic and exergetic analyses. Energy 46, 283-294. http://dx.doi.org/10.1016/j.energy.2012.08.021.

Calise, F., Vanoli, L., 2012. Parabolic trough photovoltaic/thermal collectors: design and simulation model. Energies 5, 4186-4208. http://dx.doi.org/10.3390/en5104186.

Cappelletti, A., Catelani, M., Ciani, L., Kazimierczuk, M.K., Reatti, A., 2016. Practical issues and characterization of a photovoltaic/thermal linear focus 20X solar concentrator. IEEE Trans. Instrum. Meas. 65, 2464-2475. http://dx.doi.org/10.1109/ TIM.2016.2588638.

Cappelletti, A., Reatti, A., Martelli, F., 2015a. Numerical and experimental analysis of a $\mathrm{CPV} / \mathrm{T}$ receiver suitable for low solar concentration factors. Energy Procedia 82,
724-729. http://dx.doi.org/10.1016/j.egypro.2015.11.798.

Cappelletti, A., Spadi, A., Reatti, A., 2015b. Performances issue's analysis of an innovative low concentrated solar panel for energy production in buildings. Energy Procedia 81, 22-29. http://dx.doi.org/10.1016/j.egypro.2015.12.055.

Catelani, M., Ciani, L., Kazimierczuk, M.K., Reatti, A., 2016. Matlab PV solar concentrator performance prediction based on triple junction solar cell model. Measurement 88, 310-317. http://dx.doi.org/10.1016/j.measurement.2016.03.046.

Chemisana, D., 2011. Building integrated concentrating photovoltaics: a review. Renew. Sustain. Energy Rev. 15, 603-611. http://dx.doi.org/10.1016/j.rser.2010.07.017.

Chemisana, D., Rosell, J.I., 2011. Design and optical performance of a nonimaging Fresnel transmissive concentrator for building integration applications. Energy Convers. Manage. 52, 3241-3248. http://dx.doi.org/10.1016/j.enconman.2011.05.006.

Cole, A., Heasman, K.C., Mellor, A., Roberts, S., Bruton, T.M., 2006. Laser grooved buried contact solar cells for concentration factors up to 100x. In: 2006 IEEE 4th World Conference on Photovoltaic Energy Conference. IEEE, pp. 834-837. doi:http://dx. doi.org/10.1109/WCPEC. 2006.279586.

Consorzio LAMMA, 2016. Laboratorio di Monitoraggio e Modellistica Ambientale per lo sviluppo sostenibile - Laboratory for Meteorology and Environmental Modelling.

Coventry, J.S., 2005. Performance of a concentrating photovoltaic/thermal solar collector. Sol. Energy 78, 211-222. http://dx.doi.org/10.1016/j.solener.2004.03.014.

D'Agostino, D., Parker, D., 2018. A framework for the cost-optimal design of nearly zero energy buildings (NZEBs) in representative climates across Europe. Energy 149, 814-829. http://dx.doi.org/10.1016/j.energy.2018.02.020.

Deng, S., Wang, R.Z., Dai, Y.J., 2014. How to evaluate performance of net zero energy building - A literature research. Energy 71, 1-16. http://dx.doi.org/10.1016/j. energy.2014.05.007.

Elbreki, A.M., Alghoul, M.A., Al-Shamani, A.N., Ammar, A.A., Yegani, B., Aboghrara, A.M., Rusaln, M.H., Sopian, K., 2016. The role of climatic-design-operational parameters on combined PV/T collector performance: A critical review. Renew. Sustain. Energy Rev. 57, 602-647. http://dx.doi.org/10.1016/j.rser.2015.11.077.

Gaëtan Masson, Latour, M., Rekinger, M., Theologitis, I.-T., Papoutsi, M., 2017. GLOBAL MARKET OUTLOOK For Photovoltaics 2013-2017.

Good, C., 2016. Environmental impact assessments of hybrid photovoltaic-thermal (PV/ T) systems - A review. Renew. Sustain. Energy Rev. 55, 234-239. http://dx.doi.org/ 10.1016/j.rser.2015.10.156.

Good, C., Chen, J., Dai, Y., Hestnes, A.G., 2015. Hybrid photovoltaic-thermal systems in buildings - a review. Energy Procedia 70, 683-690. http://dx.doi.org/10.1016/j. egypro.2015.02.176

Heasman, K.C., Brown, L.M., Cole, A., Devenport, S., Drew, K., Morrison, D., Bruton, T.M., Serenelli, L., Iuliis, S.De., Roca, F., 2011. 20\% laser grooved buried contact Cz silicon solar cells for the Apollon project. In: Proceeding of 26th European Photovoltaic Solar Energy Conference. Hamburg, Germany, pp. 5-9.

Heasman, K.C., Cole, A., Brown, M., Roberts, S., Devenport, S., Baistow, I., Bruton, T.M., 2007. Process development of laser grooved buried contact solar cells for use at concentration factors up to 100x. In: Proc. 22nd EU-PVSEC, pp. 1511-1512.

IES-Solare, 2017. Commercial Bullettin - Photovoltaic modules nad plant proce list Commercial Bullettin.

Iommi, M., 2016. The natural light in the Italian rationalist architecture of Ex G.I.L. of Mario Ridolfi in Macerata. The virtual reconstruction and the daylight analysis of the original building. Energy Build. 113, 30-38. http://dx.doi.org/10.1016/j.enbuild. 2015.12.041.

Ji, X., Li, M., Lin, W., Wang, W., Wang, L., Luo, X., 2012. Modeling and characteristic parameters analysis of a trough concentrating photovoltaic/thermal system with gaas and super cell arrays. Int. J. Photoenergy 2012, 1-10. http://dx.doi.org/10.1155/ 2012/782560.

Jiang, S., Hu, P., Mo, S., Chen, Z., 2010. Optical modeling for a two-stage parabolic trough concentrating photovoltaic/thermal system using spectral beam splitting technology. Sol. Energy Mater. Sol. Cells 94, 1686-1696. http://dx.doi.org/10.1016/ j.solmat.2010.05.029.

Kosmadakis, G., Manolakos, D., Papadakis, G., 2011. Simulation and economic analysis of a CPV/thermal system coupled with an organic Rankine cycle for increased power generation. Sol. Energy 85, 308-324. http://dx.doi.org/10.1016/j.solener.2010.11. 019.

Kostic, L.T., Pavlovic, T.M., Pavlovic, Z.T., 2010. Influence of reflectance from flat aluminum concentrators on energy efficiency of PV/Thermal collector. Appl. Energy 87, 410-416. http://dx.doi.org/10.1016/j.apenergy.2009.05.038.

Kribus, A., Kaftori, D., Mittelman, G., Hirshfeld, A., Flitsanov, Y., Dayan, A., 2006. A miniature concentrating photovoltaic and thermal system. Energy Convers. Manage. 47, 3582-3590. http://dx.doi.org/10.1016/j.enconman.2006.01.013.

Labayrade, R., Jensen, H.W., Jensen, C., Lyon, U. De, Ecole, F., Publics, T., Etat, D., Génie, D., Audin, M., 2009. Validation of Velux Daylight Visualizer 2 Against Cie 171: 2006 Test Cases. Build. Simul. 2009, Elev. Int. IBPSA Conf. 3, pp. 1506-1513.

Lamnatou, C., Chemisana, D., 2017. Photovoltaic/thermal (PVT) systems: A review with emphasis on environmental issues. Renew. Energy 105, 270-287. http://dx.doi.org/ 10.1016/j.renene.2016.12.009.

Li, M., Ji, X., Li, G., Wei, S., Li, Y., Shi, F., 2011. Performance study of solar cell arrays based on a trough concentrating photovoltaic/thermal system. Appl. Energy 88, 3218-3227. http://dx.doi.org/10.1016/j.apenergy.2011.03.030.

Linderman, R.J., Judkins, Z.S., Shoecraft, M., Dawson, M.J., 2012. Thermal performance of the sunpower alpha-2 PV concentrator. Photovoltaics, IEEE J. http://dx.doi.org/ 10.1109/JPHOTOV.2011.2178397.

Marion, W.F., Dobos, A.P., 2013. Rotation Angle for the Optimum Tracking of One-Axis Trackers. doi:http://dx.doi.org/10.2172/1089596.

Marique, A.F., Reiter, S., 2014. A simplified framework to assess the feasibility of zeroenergy at the neighbourhood/community scale. Energy Build. 82, 114-122. http:// dx.doi.org/10.1016/j.enbuild.2014.07.006. 
Masters, G.M., 2004. Renewable and Efficient Electric Power Systems. John Wiley \& Sons, Inc., Hoboken, NJ, USA. doi:http://dx.doi.org/10.1002/0471668826.

Meller, Y., Kribus, A., 2013. Kaleidoscope homogenizers sensitivity to shading. Sol. Energy 88, 204-214. http://dx.doi.org/10.1016/j.solener.2012.11.010.

Mittelman, G., Kribus, A., Dayan, A., 2007. Solar cooling with concentrating photovoltaic/thermal (CPVT) systems. Energy Convers. Manage. 48, 2481-2490. http://dx. doi.org/10.1016/j.enconman.2007.04.004.

Mittelman, G., Kribus, A., Mouchtar, O., Dayan, A., 2009. Water desalination with concentrating photovoltaic/thermal (CPVT) systems. Sol. Energy 83, 1322-1334. http:// dx.doi.org/10.1016/j.solener.2009.04.003.

Norton, B., Eames, P.C., Mallick, T.K., Huang, M.J., McCormack, S.J., Mondol, J.D., Yohanis, Y.G., 2011. Enhancing the performance of building integrated photovoltaics. Sol. Energy 85, 1629-1664. http://dx.doi.org/10.1016/j.solener.2009.10. 004.

Otanicar, T.P., Theisen, S., Norman, T., Tyagi, H., Taylor, R.A., 2015. Envisioning advanced solar electricity generation: Parametric studies of CPV/T systems with spectral filtering and high temperature PV. Appl. Energy 140, 224-233. http://dx.doi. org/10.1016/j.apenergy.2014.11.073.

Piratheepan, M., Anderson, T.N., 2017. Performance of a building integrated photovoltaic/thermal concentrator for facade applications. Sol. Energy 153, 562-573. http://dx.doi.org/10.1016/j.solener.2017.06.006.

Piratheepan, M., Anderson, T.N., 2015. Natural convection heat transfer in façade integrated solar concentrators. Sol. Energy 122, 271-276. http://dx.doi.org/10.1016/j. solener.2015.09.008.

Pysolar, 2013. Http://pysolar.org/.

Python, 2016. http://www.python.com.

Quaia, S., Lughi, V., Giacalone, M., Vinzi, G., 2012. Technical-economic evaluation of a combined heat and power solar (CHAPS) generator based on concentrated photovoltaics. In: International Symposium on Power Electronics Power Electronics, Electrical Drives, Automation and Motion. IEEE, pp. 1130-1135. doi:http://dx.doi. org/10.1109/SPEEDAM.2012.6264581.

Rabl, A., 1976. Optical and thermal properties of compound parabolic concentrators. Sol. Energy 18, 497-511. http://dx.doi.org/10.1016/0038-092X(76)90069-4.

Reatti, A., Beltramini, M., 2008. $20 \mathrm{X}$ concentrating PV system with thermal energy recovery for residential applications. In: Proceedings of World Renewable Energy Congress X and Exhibition. doi:10.4229/23rdEUPVSEC2008-1DV.3.32.

Reatti, A., Kazimierczuk, M.K., Catelani, M., Ciani, L., 2017. Monitoring and field data acquisition system for hybrid static concentrator plant. Measurement 98, 384-392. http://dx.doi.org/10.1016/j.measurement.2015.06.022.

Reda, I., Andreas, A., 2004. Solar position algorithm for solar radiation applications. Sol. Energy 76, 577-589. http://dx.doi.org/10.1016/j.solener.2003.12.003.

Rosell, J.I., Vallverdú, X., Lechón, M.A., Ibáñez, M., 2005. Design and simulation of a low concentrating photovoltaic/thermal system. Energy Convers. Manage. 46, 3034-3046. http://dx.doi.org/10.1016/j.enconman.2005.01.012.

Sathe, T.M., Dhoble, A.S., 2017. A review on recent advancements in photovoltaic thermal techniques. Renew. Sustain. Energy Rev. 76, 645-672. http://dx.doi.org/10. 1016/j.rser.2017.03.075.

Serri, L., Beltramini, M., Reatti, A., 2009. Design and optimization of a printed circuit board for a photovoltaic and thermal linear solar concentrator. In: Power Electron. Appl. 2009. EPE '09. 13th Eur. Conf., pp. 1-10.
Sharaf, O.Z., Orhan, M.F., 2015a. Concentrated photovoltaic thermal (CPVT) solar collector systems: Part I - Fundamentals, design considerations and current technologies. Renew. Sustain. Energy Rev. 50, 1500-1565. http://dx.doi.org/10.1016/j.rser. 2015.05.036.

Sharaf, O.Z., Orhan, M.F., 2015b. Concentrated photovoltaic thermal (CPVT) solar collector systems: Part II - Implemented systems, performance assessment, and future directions. Renew. Sustain. Energy Rev. 50, 1566-1633. http://dx.doi.org/10.1016/ j.rser.2014.07.215.

Siecker, J., Kusakana, K., Numbi, B.P., 2017. A review of solar photovoltaic systems cooling technologies. Renew. Sustain. Energy Rev. 79, 192-203. http://dx.doi.org/ 10.1016/j.rser.2017.05.053.

Skoplaki, E., Palyvos, J.A., 2009. On the temperature dependence of photovoltaic module electrical performance: A review of efficiency/power correlations. Sol. Energy 83, 614-624. http://dx.doi.org/10.1016/j.solener.2008.10.008.

Soori, P.K., Vishwas, M., 2013. Lighting control strategy for energy efficient office lighting system design. Energy Build. 66, 329-337. http://dx.doi.org/10.1016/j. enbuild.2013.07.039.

Tourkov, K., Schaefer, L., 2015. Performance evaluation of a PVT/ORC (photovoltaic thermal/organic Rankine cycle) system with optimization of the ORC and evaluation of several PV (photovoltaic) materials. Energy 82, 839-849. http://dx.doi.org/10. 1016/j.energy.2015.01.094.

Trading, P., 2017. PRICE INDEX [WWW Document]. URL http://www.pvxchange.com/ priceindex/ (accessed 4.19.18).

Visa, I., Duta, A., 2016. Innovative solutions for solar thermal systems implemented in buildings. Energy Procedia 85, 594-602. http://dx.doi.org/10.1016/j.egypro.2015. 12.249.

Vivar, M., Everett, V., Fuentes, M., Thomsen, E., Harvey, J., Ebert, M., le Lievre, P. Greaves, M., Tanner, A., Blakers, A., 2012. Results from the first ANU-chromasun CPV-T microconcentrator prototype in Canberra, pp. 114-117. doi:http://dx.doi.org/ 10.1063/1.4753847.

Weinstock, D., Appelbaum, J., 2004. Shadow variation on photovoltaic collectors in a solar field. In: 2004 23rd IEEE Convention of Electrical and Electronics Engineers in Israel. IEEE, pp. 354-357. doi:http://dx.doi.org/10.1109/EEEI.2004.1361164.

Whitfield, G., Bentley, R., Weatherby, C., Hunt, A., Mohring, H.-D., Klotz, F., Keuber, P. Miñano, J., Alarte-Garvi, E., 1999. The development and testing of small con centrating PV systems. Sol. Energy 67, 23-34. http://dx.doi.org/10.1016/S0038092X(00)00045-1.

Wu, Y., Connelly, K., Liu, Y., Gu, X., Gao, Y., Chen, G.Z., 2016. Smart solar concentrators for building integrated photovoltaic façades. Sol. Energy 133, 111-118. http://dx. doi.org/10.1016/j.solener.2016.03.046.

Yoshino, M., Mori, T., Mori, M., Takahashi, M., Yoshida, S., Shirasawa, K., 1997. Development of photovoltaic modules integrated with a metal curtain wall. Sol. Energy Mater. Sol. Cells 47, 235-242. http://dx.doi.org/10.1016/S0927-0248(97) 00044-5.

Yoshino, M., Nakada, N., Mori, T., Yamagishi, K., Yoshida, S., Higashi, Y., Shirasawa, K., 1994. Photovoltaic modules integrated with a metal curtain wall. In: Proceedings of 1994 IEEE 1st World Conference on Photovoltaic Energy Conversion - WCPEC (A Joint Conference of PVSC, PVSEC and PSEC). IEEE, pp. 969-972. doi:http://dx.doi. org/10.1109/WCPEC.1994.520122. 